\title{
Network Device
}

National Cancer Institute

\section{Source}

National Cancer Institute. Network Device. NCI Thesaurus. Code C50081.

A collection of two or more computers and associated devices that are linked together with communications equipment. 